\title{
Development of "Deutsch Für Touristmus" Teaching Based On Livejournal Website to Improve Student Competence in Tourism
}

\author{
Herlina Jasa Putri Harahap, ${ }^{1}$ Indah Aini ${ }^{2}$ \\ 1,2 Lecturer in Department of German Education, Faculty of Languages and Arts, Universitas Negeri \\ Medan, Indonesia \\ Email: herlinajasaputriharahap76@gmail.com
}

\begin{abstract}
This research is a research conducted to develop teaching materials as a means of supporting teaching and learning in the classroom in order to improve the competence and skills of students in the field of tourism in particular becoming a professional tour guide (Reiseführer / in). This teaching material is used as reference material and guidance by students in learning the Deutsch Fuer Touristmus. This study uses a development research approach using the ADDIE model conducted at the Unimed German Language Education Program. The object of this research is the development of Deutsch Für Touristmus course teaching materials. The data collection technique is used to collect data through observation, interviews and questionnaires and tests, while data analysis techniques are done using qualitative descriptive analysis, and testing of teaching materials is carried out in small groups and large groups. The results of the expert material assessment obtained values from the aspect of content worthiness of 91.67 which were categorized as very feasible, from the specs of Livejournal-based teaching materials on teaching materials included in the feasible category with a value of 80, from the aspect of language eligibility gained a value of $95.45 \%$ which was categorized very worthy. In the aspect of presentation feasibility, the value is 83.75 which is categorized as feasible and based on data from the results of the assessment of media experts, the feasibility aspect of obtaining a value of 86.25 is categorized as feasible.
\end{abstract}

Keywords: development; textbooks; Deutsch Für Touristmus; tourism

\section{Introduction}

Literary German Language Education is one of the Study Programs at the Faculty of Languages and Arts, Medan State University (UNIMED). As an educational institution, the Unimed Foreign Language Department is equipped with curriculum designs that have been adapted to the needs of the labor market which are expected to produce graduates not only as educators, but can become experts in various fields, such as tourism which have German language skills in tourism and highly dedicated who meet the standard requirements to be able to face future challenges and high competitiveness in the era of the industrial revolution 4.0, meaning that the role of graduates will also be very large in the field of tourism. In the Deutsch Für Touristmus course students are required to be able to understand the nature of tourism and the profession in the field of tourism, one of which is a tour guide (Reiseführer / in). Tourism learning is very important to be applied in the German Language Education Program, given the increasing number of students and graduates who are part-time and full-time professionals as tour guides.

Based on observations made by researchers during the lecture process Deutsch Für Touristmus, there are still students who have not been able to speak in telling attractions, especially those in North Sumatra in German. Students feel insecure and not brave because their mastery of German language is still low and they are less able to use German expressions in the 
field of tourism given the limitations of learning resources that students have. The results of the Tracer Study data of the German Language Study Program show that graduates of this study program work not only as German language teachers but there are those who work as tour guides, work in hotels, in private companies and some who work in Germany as Au-Pairs and Ausbildung in a German company. Seeing the use of German graduates in the world of work, especially in the field of tourism, the Deutsch Für Tourismus course is taught in semester 3 with a weight of 4 credits.

Learning resources are one important component in the learning system which is a means to assist students in achieving learning objectives and to develop student skills, the limitations of learning resources make students not confident in determining sentences related to the tour guide profession. The development of Deutsch Für Tourismus teaching materials is one of the solutions offered to overcome the above problems because teaching material is a unit that consists of several basic competencies that are arranged systematically, operationally, and measurably and is able to make students more active and motivated to learn by learning independent or group. Students can learn the topic of the material first so that the lecturer no longer needs to provide teaching material in front of the class with conventional methods. Change the role of educators to become facilitators. The role of teaching materials only facilitates students from the material deliverers. Improve the effective and interactive learning process because lecturers have plenty of time to guide students in understanding a learning topic, and also the methods used are more varied and interactive because lecturers do not tend to lecture.

\section{Review of Literature}

\subsection{Definition of Development}

Sugiyono (2016: 297) explained that development is to produce definite products and test the benefits of these products. Furthermore Borg and Gall (in Sugiyono 2016: 28) explained that development is developing a product and validating it such as books, films, and software. From the expert opinion above, it can be concluded that development is a process of developing a product and validating the effectiveness and efficiency of the product to be produced.

\subsection{Understanding Teaching Materials}

Teaching material is one source of learning that can be interpreted as containing learning messages, both specific and general that is used for the benefit of learning (Mulyasa, 2006). Furthermore Widodo and Jasmadi in Ika Lestari (2013: 1) stated that teaching materials are a set of learning tools or tools that bris learning materials, methods, boundaries, and ways of evaluating systematically and attractively designed in order to achieve basic competencies.

From the expert opinion above it can be concluded that the role of an educator in designing or compiling teaching materials is crucial to the success of the learning process. Teaching materials are arranged systematically, operationally, and directed and are able to make students more active and creative for independent learning.

\subsection{Deutsch Für Touristmus}

Deutsch Für Touristmus is one of the courses in the Unimed German Education Study Program taught in semester 3 with a weight of 4 credits. The basic competencies expected after students graduate are students to be able to become professional tour guides and have good soft skills in the community and work environment. The methods used in this lecture are, discussion, role playing, internships and hands-on practice (being a tour guide). Deutsch Für Tourismus is a compulsory course and has a 4 SKS load. The achievement of this course was prepared to 
answer the demands of the world of work where students must be required to have competence in the field of tourism.

\subsection{Definition of Tourism}

In RI Law Number 10 Year 2009 it is explained that tourism is all activities related to tourism and is multidimensional and multidisciplinary in nature which appears as a manifestation of the needs of each person and country as well as interactions between tourists and the local community, fellow tourists, the government, local governments and entrepreneurs. Next Ismayanti (2010) states that tourism is a dynamic activity that involves many people and enlivens various fields of business.

From the explanation above it can be concluded that tourism is an industrial business that can increase rapid economic growth, provide employment opportunities for the wider community, and can increase income and living standards of the community around a particular tourist attraction.

\subsection{Livejournal Website}

The creator of the Livejournal Website was named Brad Fitzpatrick in 1999. The Livejournal Website is a global online community created for personal journals as well as a medium for internet users. Internet users can save blogs, journals and daily tasks on the livejournal website.

The livejournal website can be updated at any time and has advantages over other websites such as wordpress and other blogs. The strengths and livejournal websites are:

1. Each journal has its own web page

2. The friend list feature gives the site a strong social aspect besides the blog service.

3. Allow users to customize accounts.

4. Users can upload graphic avatars / userpics.

5. Each user has a user info page.

\section{Research Method}

This research model refers to the ADDIE development model which consists of: i) analysis, ii) design, iii) development, iv) implementation, and v) evaluation. The results of this study will be tested by material and design experts before they are given to students. Evaluation of the results of the test material and design aims to find out whether the objectives of developing Deutsch Für Touristmus courses have been achieved or have been in accordance with needs.

\section{Discussion}

The main result of this study is the design of the development of Deutsch für Touristmus teaching materials based on the Livejournal Website to improve student competency in the field of tourism. This research was conducted using the ADDIE model conducted at the Unimed German Language Education Study Program consisting of five research steps, namely:

\subsection{Analysis Phase (Analize)}

The analysis activity was carried out to determine the basic problems needed in developing Deutsch für Touristmus teaching materials based on the Livejournal Website to improve student competency in the field of tourism. At this stage an analysis of the subject 
matter is in accordance with the needs needed by tour guides in serving tourists, the facts of the learning process in the field, learning approaches that are relevant to future challenges in tourism so that a description of the learning patterns that are considered most appropriate can be implemented. The subject matter of Deutsch für Touristmus teaching materials based on the Livejournal Website to improve student competence in the field of tourism consists of 12 themes, namely; i) Tour guide skills (Reiseleiter / in), ii) Welcome to North Sumatra (Herzlich willkommen in Nord-Sumatra), iii) Welcome to the hotel (Herzlich willkommen im Hotel), iv) Restaurants (v), v) In bar (im Bar), vi) At Maimoon palace (Im Maimoon Palast), vii) On Bukit lawang Im Bukit lawang, viii) At Tjong A Fie's house (Im Tjong A Fies Haus), ix) Batak Land and Lake Toba (im Batak-Hochland und Toba-See), x) Grand Mosque (Große Moschee), xi) Berastagi (in Berastagi) and xii) Tangakahan (in Tangkahan).

\subsection{Design Phase}

The aim of this stage is to design teaching materials for the recovery of Deutsch für Touristmus based on the Livejournal Website to improve student competency in the field of tourism. First is the development of ideas. The process in this stage is that all ideas are developed. The idea is about the appearance, media and forms of tourism teaching materials that can present text and image content. The next stage is to analyze the material on teaching materials obtained from various sources in accordance with the learning objectives specified in the RPS and college contracts by considering the facts in the field. Then compile the scope of teaching material consisting of 12 chapters. Each chapter begins by including learning achievements, achievement indicators, required reading and recommended reading to make it easier for students to find other references related to learning in the chapter. Each chapter includes HOTS practice questions. The questions are designed to stimulate student mastery of the material in the chapter with a link that is connected to this internet page related to the latest and most sophisticated technology related to the material in the chapter. At the end of each chapter there is an evaluation that aims to stimulate students' scientific abilities and assess the extent to which their understanding is related to the material they have learned.

\subsection{Development Phase (Develop)}

This Deutsch für Tourismus teaching material book was developed by containing the main sections, as follows:

a. The cover / cover of teaching materials

The cover of teaching material consists of the title of the book and the author. The picture in the cover is adjusted to the learning material that is interestingly packaged. The layout of the cover page is arranged in such a way as to attract the attention of students so that a good cover appearance will motivate students to study tourism, especially Germanspeaking tour guides.

b. Foreword

Preface contains the writer's remarks on the completion of writing teaching materials both thanks, the purpose and benefits of writing as well as constructive criticism and suggestions as well as hopes for other better works.

c. table of contents

Table of contents is designed to make it easier for readers to find pages on the desired teaching material.

d. Instructions for Use of Teaching Materials

The guide component of book use is very important so that students can be possible so that the purpose of using teaching materials as well as possible and as optimal as learning can be achieved. 
e. Chapter Title, Learning Outcomes and Indicators of Achievement

Each chapter begins with a chapter title, learning achievements, achievement indicators, required reading and recommended reading to make it easier for students to know other references relating to learning in the chapter. Each chapter is designed in accordance with the basic competencies and learning objectives that are expected to be achieved by students.

f. Teaching Material

The material on teaching materials obtained from various sources in accordance with the learning objectives specified in the RPS and college contracts by considering the facts in the field for a German-speaking tour guide. Then compile the scope of teaching material consisting of 12 chapters. Each chapter begins by including learning achievements, achievement indicators, required reading and recommended reading to make it easier for students to find other references related to learning in the chapter. The material is presented in two languages, namely German and Indonesian, so that it helps students better understand the material contained in each chapter if they have difficulty studying German material, while each chapter also includes HOTS practice questions. At the end of each chapter there is an evaluation. This teaching material is designed based on the Livejournal Website to stimulate the mastery of technology in students through the provision of information related to the latest and most advanced technology related to German-language tourism material.

g. Evaluation

At the end of each chapter there are various evaluations. Evaluation contains exercises that are important in the chapter. The evaluation presents a summary of the material but is solid and complete in the form of exercise. Evaluation can make it easier for students to master the material in the chapter in depth. The evaluation aims to stimulate the ability of the tourism sector of students and assess the extent of their understanding of the material that has been studied. Through evaluation, students can practice about questions related to learning material.

h. References

At the end of the textbook there is a bibliography. This section consists of lists that contain all the books that are used as a reference in developing material presented in teaching materials. Bibliography to help students get references about German-language tourism in addition to these teaching materials. Bibliography is also important to include to avoid plagiarism and to give an overview of the novelty of the teaching material.

\subsection{Implementation}

This Deutsch für Tourismus teaching material product can be used as an additional learning resource for students in the German Language Study Program. This product can also be distributed to those who need it both within the Medan State University and outside Medan State University. Prior to distribution, this product will be submitted to the national standards body to obtain the National Book Standards Index (ISBN).

\subsection{Evaluation}

In general, the material expert assessment questionnaire consisted of 3 aspects, namely the content eligibility aspect, the feasibility aspect of presentation and the evaluation aspect of teaching materials based on the Livejournal Website. Each aspect of material validation is explained in the following tables: 
Table 1. Results of Expert Material Validation

\begin{tabular}{|l|l|l|l|}
\hline No & Assessment Aspect & $\mathbf{P ~ ( \% )}$ & Category \\
\hline 1 & Content Feasibility & 91,67 & Very feasible \\
\hline 2 & Feasibility of presentation & 83.73 & Eligible \\
\hline 3 & $\begin{array}{l}\text { Learning materials based on } \\
\text { Website Livejournal }\end{array}$ & 80 & Eligible \\
\hline
\end{tabular}

This media expert evaluation consisted of two aspects, namely the feasibility of the graphic and the feasibility of the language. The results of assessing these two aspects can be seen in the following table:

Table 2. Media Expert Validation Results

\begin{tabular}{|l|l|l|l|}
\hline No & Assessment Aspect & $\mathbf{P ~ ( \% )}$ & Category \\
\hline 1 & Feasibility of Graphic & 86.25 & Eligible \\
\hline 2 & Language Feasibility & 95,45 & Very Feasible \\
\hline
\end{tabular}

Based on the data from the expert's assessment, the feasibility aspect of the graphic obtained a value of 86.25 which was categorized as feasible. The aspect of eligibility of graphics consists of several assessment indicators, namely the appraisal of the attractiveness of the livejournal website, the design of the livejournal website and the design of the contents of the livejournal website. Aspects of language worthiness get a value of $95.45 \%$ which is categorized as very feasible. The trial was conducted on 49 students of the German Anglatan Education Class 2016 Class A and Class C who had taken the Deutsch für Tourismus course the previous semester.

Table 3. Student Assessment Results on Deutsch Für Touristmus Teaching Materials Based on the Livejournal Website

Für Touristmus Berbasis Website Livejournal

\begin{tabular}{|l|l|l|l|}
\hline No & Rating Indicator & Value (\%) & Category \\
\hline 1 & Visual (Design and Layout) & 90,35 & Very Good \\
\hline 2 & $\begin{array}{l}\text { Attracting Content of Very Good } \\
\text { Material Language }\end{array}$ & 84,35 & Good \\
\hline 3 & Languages 84,35 & 84,35 & Good \\
\hline 4 & $\begin{array}{l}\text { Content of Material Related to } \\
\text { Website Livejournal }\end{array}$ & 86,46 & Good \\
\hline 5 & Student Assistance in Learning & 84,10 & Good \\
\hline
\end{tabular}

The results of the student assessment of the Deutsch für Tourismus teaching materials showed that the value of teaching materials in the visual aspects (design and layout) was 90.35\% with a very good category. The results of student assessment of the attractiveness aspects of the contents of teaching materials showed a value of $84.01 \%$ with a good category. Student assessment of the language used in teaching materials scored $84.35 \%$ with a good category. The material content aspect related to the Livejournal Website scored $86.46 \%$ with a good category. This means that students consider the material quite easy to understand even though there are certain parts that are difficult to understand. The aspect of student assistance in learning scored $84.10 \%$ in the good category. Students assume that the presentation of material in this teaching material encourages them to discuss with their friends. In addition, this teaching material encourages student curiosity related to the development of science and technology in the field of tourism through the Livejournal Website. 


\section{Conclusion}

Based on the results of the study it can be concluded that, the development of Deutsch für Tourismus teaching materials based on the Livejournal Website to improve students' abilities in the field of tourism uses ADDIE Modell theory which consists of five facages, namely: a) Analysis (Analyze), b) Design (Design ), c) Development (d), d) Implementation (e) and e) Evaluation (Evaluation). The feasibility of Deutsch für Tourismus teaching materials based on the LiveJournal Website to improve the ability of students in the field of tourism is based on the assessment of material experts and media experts in terms of content, linguistic, presentation, and graphic aspects. Based on data from the results of expert material assessment, the aspect of content eligibility obtained a value of 91.67 which was categorized as very feasible. The aspect of teaching materials based on the Livejournal Website in teaching materials is included in the feasible category with a value of 80 . This means that the contents of teaching materials included on the Livejournal Website are included in the feasible category. Aspects of language worthiness get a value of $95.45 \%$ which is categorized as very feasible. This implies that this teaching material uses straightforward language both in German and in its Indonesian language. In the aspect of presentation feasibility, the value is 83.75 which is categorized as feasible. Based on the data from the expert's assessment, the feasibility aspect of the graphic obtained a value of 86.25 which was categorized as feasible.

\section{References}

Harahap, H., J., P. (2015). The Application of Pictogram Learning Media as an Effort to Increase Student Competence in the Schreibfertigkeit III Course, in the March 2015. Journal of Edition, ISSN: 2442-7594. Medan: FBS Unimed

Development of Learning Media Using Lectora Inspire Software to Improve Writing Ability, in the International Journal of Academic Research in Education and Review. Volume 7. ISSN 236078662019

Ismayanti. (2010). Introduction to Tourism. PT.Grasindo, Jakarta

Kristianto, Y. (2017). German for Tourism in the Tourism Travel Industry, Tourism Destinations and the Hospital Hospital Industry. ANDI, Yogyakarta

Lestari, I. (2013). Development of Competency Based Teaching Materials. Akademia. Padang

Mulyasa, (2006). Becoming a Professional Teacher Creates Creative and Enjoyable Learning. PT. Teen Rosdakarya. Bandung

Rusman. (2011). Learning Models Developing Teacher Professionalism. PT. Raja Grafindo Persada, Jakarta

Sugiyono. (2016). Research and Development Methods. Bandung: Alfabeta.

Livejournal website. Id.m.wikipedia.org

http://chikasproject.blogspot.com/2014/03/live.journal.html

Republic of Indonesia Law Number 10 Year 2009 